\title{
From Mombasa to Khartum: Through Uganda and down the Nile
}

\author{
Sir Charles Eliot K.C.M.G. C.B.
}

To cite this article: Sir Charles Eliot K.C.M.G. C.B. (1906) From Mombasa to Khartum:

Through Uganda and down the Nile, Scottish Geographical Magazine, 22:7, 341-354, DOI:

$10.1080 / 14702540608521195$

To link to this article: http://dx.doi.org/10.1080/14702540608521195

曲 Published online: 30 Jan 2008.

Submit your article to this journal $\lceil\pi$

Џll Article views: 6

Q View related articles 5 


\title{
THE SCOTTISH
}

\section{GEOGR A P H I C A L}

\author{
MA GAZINE.
}

\section{FROM MOMBASA TO KHARTUM: THROUGH UGANDA AND DOWN THE NILE.}

By Sir Charles Eliot, K.C.M.G., C.B.

Is the lecture which I am about to give, I shall ask jou to accompany me to the somewhat remote regions which contain the sources and upper waters of the Nile. I visited them myself in July and August 1902, travelling along the Nile, and often on it, the whole way from Lake Victoria to Khartum, Aswan and Cairo. Probably to most of $\mathbf{m y}$ hearers Khartum will seem a distant spot in the heart of Africa, but to me, as $I$ descended the river, it appeared as the beginning of civilisation and the fringe of Europe, and in this lecture I am almost entirely concerned with the Nile south of Khartum, and more particularly with the parts of it which lie to the south of the Sobat, that is to say those which lie between the Equator and eight degrees to the north of it.

Perhaps it may be well to briefly sketch the course of the Nile. It has a double course. That is to say it issues from the northern end of Lake Albert, but immediately before this river leaves Lake Albert, the lake receives another river coming from Lake Victoria on the east, and known as the Victoria Nile. Accordingly the stream which issues from Lake Albert is composed not only of the waters of that Lake, but also of the waters sent on from Lake Victoria which leave Lake Albert at very nearly the same point as they enter it. Lake Albert is also connected by the river Semliki with Lake Albert Edward, which lies to the south of it, and these three lakes, Victoria, Albert, and Albert Edward, are the reservoirs from which the Nile draws its waters until it reaches the Sudan, where it loses much of its bulk in swamps, but is also recruited by several important tributaries. The river which issues 
from Lake Albert is known as the Bahr-el-Gebel or mountain river. For about 150 miles it is navigable though not deep, but after Nimule the rocks close round it and it is rendered impassable by rapids until near Gondokoro, from which point continuous navigation is possible up to Khartum. Gondokoro belongs to the Uganda Protectorate, but immediately beyond it begin the territories of the Egyptian Stdan, and the Nile undergoes a most curious transformation-one may almost say catastrophe-it spreads out into an enormous marsh in which it loses the appearance of a great river and becomes a swamp with a narrow and tortuous navigable channel, often very difficult to find. This is the region of the Sudd, of which more anon. Naturally the waste of water is considerable, and much of the water supplied by the Equatorial Lakes never gets through this marsh at all; but the loss is not apparent

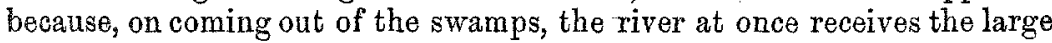
tributary known as the Bahr-el-Ghazal coming from the west. At the same time it makes a sharp bend to the east and shortly afterwards receives the Sobat on its right bank. It is now called the White Nile and resumes its northerly direction, and flows on about 840 miles to Khartum, where it receives the Bahr-el-Azrek or Blue Nile from Lake Tsana in Abyssinia. The total distance by river from Lake Victoria to Khartum is about 1700 miles.

These facts about the course of the Nile have only been known for certain in the last forty years. The honour of their discovery is divided between many eminent travellers, but perhaps the largest share of glory falls to Speke. In 1858 he made an expedition from the East Coast of Africa to the interior in company with Burton and discovered Lake Tanganyika. Burton fell ill, and Speke parting from him, struck to the north and discovered the southern end of Lake Victoria. A year or two later he organised a second expedition in conjunction with Grant, in which he not only increased our knowledge of Lake Victoria, but after many delays succeeded in making his way to Alexandria from that lake, and thus demonstrated that it is one of the sources of the Nile. He did not see Lake Albert, though he knew of its existence, and correctly marked its position from hearsay. This lake was first seen in 1864 by Sir Samuel Baker, who reached it from the north after meeting with Speke. Though the principal points in the course of the Nile had thus been established, much doubt and obscurity still prevailed owing to confused ideas respecting the basins of the Nile and Congo, which were not properly separated. The matter was cleared up by Stanley. In his first journey, in which he started from Zanzibar, he circumnavigated Lake Victoria and explored Uganda and the neighbouring countries. In his second and more celebrated journey he struck straight across Africa, and discovered among many other things Lake Albert Edward and the snow mountains of Ruwenzori.

On this occasion Stanley crossed Africa from west to east, but the easiest route for reaching the sources of the Nile is from the East Coast. We are apt to think of the Nile as a Central African river, and the traveller in its upper waters feels plunged in the inaccessible heart of the continent. But in reality the Nile is an East African stream. If 
we take longitude $20^{\circ}$, which passes almost through the Cape of Good Hope, as marking the centre of the continent, the course of the Nile lies ten degrees to the east of this line, and its longest tributaries hardly come within five degrees of it, while, if we take the maximum breadth of Africa from Cape Verde to Cape Guardafui, the Nile will be found to be contained in the eastern third, and almost in the eastern fourth, of the continent. It will also be seen that all the great tributaries of the Nile, except the Bahr-el-Ghazal, come from the east. Lake Albert, however, is not inaccessible from the west. Steamers proceed up the Congo and its tributary the Aruwimi, and the Belgian Government are doing their best to improve the communication between the point where navigation stops and the shores of the Lake. But I believe there still remains an intervening region of thick forest which it takes some weeks to traverse. The journey from the East Coast, on the other hand, is surprisingly easy. As you are no doubt aware, a British line about 600 miles long, known as the Uganda Railway, connects Mombasa on the coast with Lake Victoria. A service of Lake steamers corresponds with the trains, and will take the traveller either to Entebbe, the official capital of Uganda, or to Jinja, at the point where the Victoria Nile issues from the Lake. The shortest and healthiest route is to avoid the Victoria Nile and march or drive straight across Uganda, to Lake Albert. From here a rowing and sailing boat can reach Nimule at the head of the rapids in about five days. From this point the traveller must march to Gondokoro, which takes about six days. At Gondokoro the river again becomes navigable, and a small steamer can proceed to Khartum without much difficulty. At Khartum one takes the railway to Wady Halfa. From Wady Halfa to Philae and Aswan is a journey of two days by steamer, and another day's rail brings one to Cairo. This is the route over which I ask you to accompany me. I myself did the whole journey from Mombasa to Cairo in 51 days, including several stoppages of two or three days on the way and an enforced detention of five days owing to the breakdown of a steamer. Now that the steamer service is better arranged, I should think the distance might easily be covered in five weeks, allowing for time to look round on the way, and if any one organised his journey carefully beforehand, and was willing to travel quickly, $I$ think he ought to be able to reach Cairo from Mombasa in a month.

Mombasa, the terminus of the Uganda Railway on the Coast, is an old Arab settlement, first made known to Europeans by Vasco da Gama, who touched there during his first voyage round the Cape to India in 1498. Is is situated on a small island surrounded by considerable harbours on two sides, but so closely fitted into the coast that its separate existence is not discernible on the map, though the channel which divides it from the mainland is wide enough to require a considerable bridge. However, it is not my purpose to-night to describe the Uganda Railway, and I must hurry over it with a rapidity out of all proportion to the rate of the train, which does not number speed among its many excellences. The first two hundred miles of the journey are spent in traversing a jungle, after which the train emerges upon plains about 
5000 feet high and remarkable for their fine climate as well as for the number of zebras and beautiful wild antelopes which they support. After mounting to a height of 7000 feet, the railway descends into a great depression called the Rift Valley, consisting of a huge natural trough containing a series of lakes. There are two of these troughs in the Eastern side of Africa : first of all the present one, about 350 miles from the sea, extending into Abyssinia in the north and German East Africa in the south, and containing Lakes Naivasha, Rudolf, and others; secondly, a larger depression about 300 miles further to the west, containing Lakes Tanganyika, Kivu, Albert Edward, and Albert. It is from this second valley that the Nile issues, and it is hence sometimes called the Nile Rift Valley; but it must be remembered that, though Lakes Albert and Albert Edward are connected by the Semliki river, and Lakes Kivu and Tanganyika by the Rusizi, there is no connection between these last two and Lake Albert Edward, and they cannot be said to in any way contribute to the formation of the Nile.

After traversing the first of these Rift Valleys, the railway scales the very considerable elevation known as the Mau Escarpment, and attains a height of 8000 feet, after which it descends rapidly, by means of a striking system of viaducts, more than 4000 feet and reaches the shores of Lake Victoria, which are about 3800 feet above the sea level. We must pay a little more detailed attention to this great sheet of water, as it is one of the principal sources of the Nile.

It lies between the two Rift Valleys already mentioned, but does not belong to either of them, and it seems equally certain that it is not an old arm of the sea, as so many African Lakes have been supposed to be, bat merely a depression in which the rain which falls on the surrounding country collects. At least fifteen rivers flow into it and become considerable streams in the wet season when the rain is prolonged and heavy. The largest of them is the Kagera, which may thus be regarded as one of the ultimate sources of the Nile. The country within a few miles of the Lake shore is in most parts swampy and unhealthy for Europeans, though thickly populated by natives. But even these latter suffer severely from sleeping sickness, an incurable disease which seems to be transmitted by the bite of a fly that lives in trees near water.

Unlike the Albert Nyanza and many other African lakes, Lake Victoria is not very picturesque, and at any rate in British territory affords few fine views. This is because the shores are low and indented and often fringed with islands, so that the water seen at many pointsfor instance Kisumu, the railway terminus-is not the whole lake, but merely an arm or bay. But the dimensions are imposing, as the whole sheet of water is about 265 miles long from north to south, and about 215 broad. The steamer usually takes more than twenty-four hours to cross, as it stops to take in wood fuel and does not travel at night because islands are numerous and imperfectly surveyed.

The Victoria Nile issues from this lake at Jinja, about the middle of the northern end just above the Equator, and the point of exit is known as the Ripon Falls. Considered as a water-fall this 
cascade is not remarkable, for the drop is small, but the immense volume of blue water rushing between a gorge of red cliffs is an impressive sight. In the midst of this whirling stream are a few quiet pools formed by the backwaters of the eddies. The fish who are carried down by the river collect in them and appear to be quite dazed and stunned, so that the natives are able to spear them from the bank with long poles. Water-birds also avail themselves of the dazed condition of the fish, and may be seen swimming about in the still pools capturing enormous quantities of prey.

On leaving the Ripon Falls the Nile proceeds almost due north, and after about 75 miles reaches a large but very irregularly shaped lake called Choga or Kioga, through which it runs for about 50 miles. This lake is really little more than a swamp, for it is very shallow, and large parts of its surface are covered with floating weeds. On leaving it, the river runs first north and then west to Lake Albert, and shortly before reaching that Lake dashes through a narrow gorge and forms what are known as the Murchison Falls. They are steeper and narrower than the Ripon Falls, and present a curious appearance as the flow of the water into the pool below is not regular, but consists of a series of interrupted waves accompanied by a curious intermittent roaring. It would appear that the river rushing down the long water-slide encounters some rocky obstacle just before it enters the pool. It rebounds from this obstacle, but of course the water behind follows immediately on the top of it. Ssen from below, the effect presented is a mass of water tumbling headlong into the pool and interrupted at intervals by an enormous broken wave. The drop is about 120 feet, and the basin is surrounded by quantities of crocodiles, which may often be seen basking in the sun, literally piled one on the top of another. All the country about Lake Choga is very unhealthy, and as the Murchison Falls effectually prevent every kind of navigation, it is not likely that the Victoria Nile will ever be of much importance. It is not, as a rule, followed by those who wish to go from Uganda to Egypt by the Nile.

The easiest method of reaching Lake Albert and the Bahr-el-Gebel is to avoid the Victoria Nile altogether, and to strike straight from Entebbe or Kampala across the kingdom of Unganda to Butiaba on the shores of Lake Albert, a distance of about 160 miles. I drove the whole way myself, as there is a good broad road connecting the two lakes which can be used by either carriages or motors, though its ups and downs are somewhat severe, owing to the uncompromising manner in which it scales elevations and passes through the middle of swamps, disdaining to make the smallest curve to the right or left. But on the whole it is a broad fine road, such as one is very thankful and rather surprised to find in Equatorial Africa. I was able to traverse the distance in a little over four days owing to the authorities having provided relays of mules every ten or twenty miles, but it has been found impossible to maintain these stations permanently, as neither horses nor mules thrive in this part. The almost invariable method of travelling in this country is marching, that is to say, walking from eight to twelve miles a day with a 
caravan of porters. The African races have a real genius for porterage, and it is perhaps characteristic of them that they regard the head mainly as an organ for bearing burdens; and do not associate it with thought or intellect. It is surprising to see how they will throw a box weighing $60 \mathrm{lbs}$ - - the regulation weight-on to their heads, and walk bearing it in this position for three or four hours with a perfectly erect carriage. Some tribes put the burden on their backs, but even then they support it by a strap running round the forehead, on which a great part of the weight thus falls.

The country beyond Lake Victoria which we are now traversing is called Uganda, but I must warn you that this name has a double significance. There is the Protectorate of Uganda, and the Kingdom of Uganda. The former is the general designation for all our territories in East Africa north and west of Lake Victoria, those to the east being called East Africa. The Kingdom of Uganda, though perhaps the most important part of the larger protectorate to which it gives its name, is a relatively small native state lying on the north-west shore of Lake Victoria and extending in the direction of Lake Albert until it meets another native state called Unyoro.

Uganda is, perhaps, for the general public, the best-known name in the Fastern part of Africa. Though it is a considerable distance from the coast, it attracted attention and interest in England from the time when it was first visited by Stanley in 1875 , long before we began to concern ourselves actively with the affairs of more accessible places such as Zanzibar and Mombasa. It was mainly the feeling that we could not abandon Uganda that led to the construction of the railway from Mombasa to Lake Victoria and the establishment of our East African Empire. The country is remarkable and almost unique in tropical Africa, in possessing a large and most intelligent native population, who have shown an aptitude for assimilating European education and European material civilisation which can only be paralleled in Japan. In the space of thirty years the whole country has become at least nominally Christian, and all the children learn to read and write the Roman alphabet. The difference between Uganda and the surrounding countries will be clear, if I say that in the whole stretch between the coast and Lake Victoria there is nothing constructed by natives which can be called either a town or a road, for before the arrival of Europeans there were only jungle paths and a few villages, hidden as much as possible in the woods; there was nothing which could be called a state or a government, and the chiefs, as a rule, had authority only in their own villages. Many of the tribes went absolutely naked, and all were, according to our ideas, very imperfectly clad. It must be added that most of these tribes have shown very little capacity for advancing beyond this condition. In Uganda, on the contrary, when it was first discovered, there was a well-developed social system with lower and middle classes, a territorial aristocracy, and a central government culminating in a king and an elaborate court; the people were clothed in flowing garments made of fibrous bark, and the capital had a population of 80,000 and contained large wooden houses, which, if not very magnificent according 
to our ideas, may be called palatial in comparison with the huts generally built by African natives. The government, it is true, was marked by great cruelty and tyranny, but it showed a genuine desire to unite the whole people in one state, an idea totally foreign to most savage tribes in Africa. Under British guidance this government has been transformed into a constitutional monarchy, which appears to work satisfactorily. The change is perhaps facilitated by the fact that the present king, who has already been on the throne about six years, is a minor aged eight or nine, who is thus growing up among new conditions and becoming gradually accustomed to them. At present authority is vested in three regents and in an elective parliament, and there is a well-organised system of administering justice and an effective police force. The remoteness of Uganda has somewhat hampered its development, but the natives possess two qualities which ensure that they will in the future play a prominent part in these regions. First, they are anxious to purchase European goods, not merely toys, but machinery and building materials. Even five years ago many of the chiefs had electric bells in their houses, and there is a general desire to develop the resources of the country by European methods. Secondly, the people have a passion for education. It is a reproach not to be able to read, and there is probably no country in the world where missionaries have received so hearty a welcome or made such striking progress.

All this part of Africa-and one may perhaps say all tropical Africa except such parts in the south and east as form high, open plains-is remarkable for the thickness of its vegetation, and one result of this is that the population and their houses are much less conspicuous than in other countries. Kampala, the capital of Uganda, is built, like Rome, on seven hills, and as most of them are crowned by a building of some size, such as a cathedral, a palace, or a fort, the site is conspicuous from a distance. But when one looks down on the city from the top of one of these hills, one sees few traces of its 80,000 inhabitants, but merely a sea of deep green. This is because all the houses are built within gardens containing banana-trees, which surround and overshadow them. The same feature is still more remarkable in the interior. As one travels across the country, one seems to be always going through a forest or between tall grass. Though there are many large and gorgeous flowers in Africa, they do not often grow in masses or sensibly affect the colour of the landscape, which is generally deep, dead green. One passes houses now and then on the road, and sees people going to or from market, but the towns are in general hidden, and considering the density of the population and the numbers of wild animals in the country, the signs of both man and beast are surprisingly small.

About twenty-five miles from Lake Albert, one passes through the large town of Hoima, the capital of Unyoro, a native state similar to Uganda, but less known and less progressive, inasmuch as it is further from the coast. The first view of the lake is sudden, and strikingly unlike Lake Victoria. It is surronuded by high cliffs which leave only a narrow rim of flat shore between their base and the water, and as one comes from the east one issues from a forest, turns a corner, and in the twinkling 
of an eye sees the whole panorama spread below. When I saw the lake it was largely of a bright green colour, due to the presence in enormous quantities of some minute organism which renders it unfit for drinking. But I believe that this phenomenon is only occasional.

Lake Albert is connected by the river Semliki with Lake Albert Edward, which must therefore be regarded as one of the ultimate sources of the Nile. I have never visited it, but it is described as surrounded by high mountains, except at its southern end. The most remarkable of these is Mount Ruwenzori, perhaps the largest snow mountain or range of mountains in Africa.

The whole of this region is very subject to haze and fog, and Ruwenzori is sometimes invisible for months together. Many explorers had been quite near it without seeing it, before it was discovered by Stanley in 1888. It is probably the range called by ancient geographers the Mountains of the Moon, and has been recently ascended to a height of about 16,000 feet.

From Lake Albert to Nimule at the head of the first rapids, I proceeded in a large boat, using a sail when necessary, but generally relying on the strength of twelve native oarsmen, who rowed with unfailing regularity from sunrise to sunset, hardly seeming to care for an hour's rest in the middle of the day. This section of the Nile is perhaps the most beautiful and interesting in the whole river, excepting only Egypt itself. It is called the Bahr-el-Gebel or Mountain Nile, and both its banks are bordered by a low range of mountains, which is generally, however, at some distance from the stream. In places, particularly near Lake Albert, the banks are fairly high, but they are often quite low, the river being bounded by a shallow marsh, which renders landing extremely difficult, though it often improves the landscape, as it is covered with blue and white water lilies, and other beautiful flowers. Another vegetable which is quite a feature in the river scenery, though neither a beautiful nor a useful one, is a floating plant something like a cabbage, which may be seen sailing down the stream, trailing long roots behind it. This plant does not do much harm in this part of the Nile as it subsequently gets dashed to pieces on the rapids, but further down it gets entangled with the reeds and papyrus, and helps to form that formidable vegetable barrier called the Sudd, which long obstructed navigation in the Sudan, and of which I shall speak later.

Unlike the silent forests of Uganda, the waters and banks of the Bahr-el-Gebel are full of animal life, particularly birds. Incredible numbers of long-legged storks, cranes, and herons stand among the rushes, presumably watching for fish, but apparently contemplating the scene. Conspicuous among them are the beautiful crowned cranes, who have a crest of plumes on the head like a diadem, and the Balceniceps rex, a huge blue stork, with a broad bill shaped like a boat. Other kinds of birds run about on the flat leaves of the water-lilies, and seem to rarely venture either into the water or on to the land. Others build hanging, bottle-shaped nests on trees, and sometimes a whole colony will take possession of a tree and cover it with many hundreds of these nests. 
But the most remarkable and conspicuous animal to be seen in the river is the hippopotamus. They are extremely common, particularly in quiet pools and backwaters, where parties of twenty or thirty may often be found together. The hippopotamus when taking his ease on the shore is rather like a huge pig with a monstrously developed head, and in this part of the world, at any rate, is often quite light and almost pinkish in colour. On land their movements seem clumsy, but once in the water they are extremely active, if not precisely graceful. They appear to have the power of walking on the bottom of rivers, and the females carry their young on their backs, but from time to time they come up to the surface to breathe or bask in the sun. In districts where they have been shot at, they are extremely cautious and lie just below the surface, showing nothing but the tips of their ears and their nostrils, so that they are almost invisible, but in these wild countries where they have never been molested they throw their whole head out of the water backwards and take an enormous gulp of air. At first the effect of all these huge creatures rising round the boat was very alarming, but they appeared to be quite harmless and showed no disposition whatever to attack. It would appear that the hippopotamus is naturally a very inoffensive animal, but in some districts they have discovered that natives carry grain in boats. When once they acquire this knowledge they become extremely dangerous, for they will deliberately upset anything they find on the water in the hope that it may contain grain.

The human inhabitants of this district are known by various names, such as Madi and Bari. They differ in language, and to a certain extent in customs, but are clearly allied to one another, and form a distinct sub-division of the human race. Though they are dark in colour, they are not at all like the people who are commonly known as negroes, and I may perhaps remind you that this word negro is not really a general name for the natives of Africa, but is properly applied only to the inhabitants of the West Coast and the Congo. The natives of all those districts were in former times exported as slaves in considerable numbers to North America, the West Indies, and Brazil in all of which countries they now form a considerable proportion of the population; but most of the natives of East Africa, as well as the Zulus, Kaffirs, and other tribes of South Africa, belong to other races and often have not flat noses, thick lips, or woolly hair. The tribes who live by the Nile have a very distinct physical appearance. The men are nearly all tall, with long thin limbs, and their features are sometimes almost European in regularity, though often spoilt by knocking out the front teeth or cutting gashes in the cheeks. They have a curious habit of resting standing on one leg, placing the foot of the other against the ankle of the leg on which they are standing, and will remain for long periods in this position. But the most remarkable point in their appearance is that, although they are by no means savages, all the male sex go absolutely naked, and consider it derogatory to the dignity of a man to wear any clothes. By way of ornament they sometimes wear in their under lip one or two skewers made of polished glass, and they 
are very anxious to obtain bottles from Europeans in order to grind them down. They also sometimes wear a helmet made of the hair of their ancestors matted into a sort of felt and covered with a pattern in white beads. Even the women, though they wear a certain amount of clothes, must be regarded as belonging to the class of light dressers, and their costume consists largely of head-dresses and beads. Their villages are circular and surrounded by a wooden fence. In the middle are the store-houses for grain and other provisions, set on poles about 4 feet. high to keep them out of the reach of animals, and also a few platforms 10 or 12 feet high. These latter are used as places of repose when mosquitoes are intolerably abundant, for the mosquito rarely lives far above the ground. The dwelling houses are circular huts made of wood and thick straw, sometimes with foundations in stone.

But in all this district, though the population is not really scanty, the banks of the river seem very deserted, and one does not see more than two or three villages on the banks in the course of a day. This is because of the fear inspired by the Dervishes in former times, which drove the inhabitants away from the river and led them to build most of their villages about ten miles from the bank. You are no doubt aware that these Dervishes have played a considerable part in the history of the Sudan and the Equatorial Provinces to the south of it. As far as I know, nothing whatever is known of the history of those countries before the beginning of the last century. About 1820 the Egyptian Government founded Khartum, and during the next fifty years gradually extended its power to the south, largely through the assistance of Europeans like Sir Samuel Baker. But in 1882 a double rebellion broke out. Arabi Pasha revolted in Lower Egypt, and at the same time a religious fanatic known as the Mahdi rose in the Sudan. He annihilated the forces of General Hicks and subsequently of Gordon, and for about fifteen years his followers, known as the Dervishes, were masters of the Sudan, and though they did not permanently occupy any country near Lake Albert, they occasionally raided the upper reaches of the Nile. Their power was destroyed, as you know, by Lord Kitchener at the battle of Omdurman in 1898.

When the Mahdi's rebellion broke out and Gordon was imprisoned in Khartum, a celebrated man was governor on behalf of Egypt of the Equatorial Province, and resided at Wadelai, about two days'journey down the Nile from Lake. Albert. This was Emin Pasha, a German whose real name was Schnitzen. Owing to the Mahdi's revolt he was entirely cut off from communication with Egypt and the Sudan, and seemed to have disappeared. Stanley's celebrated expedition in 1889 was made with the object of rescuing him, and he was found living safe and sound at Wadelai and maintaining order in the district. Up to that period whatever civilisation was to be found on the upper waters of the Nile had penetrated southwards from Egypt, but after Stanley's great journey, Europeans began to frequent Uganda, whereas the Sudan remained in the hands of the Mahdi for some time. Hence the old Equatorial Province of Egypt was broken up. The Sudan, of which Khartum is the capital, extends sonthwards to about Gondo- 
koro, and the country south of this belongs to the Protectorate of Uganda and has nothing to do with Egypt. But until we reach the territory of the Sudan, only the right or east bank of the Nile is actually occupied by Great Britain. Though we have the same rights over the west bank, we have leased it to the Belgians in order to enable the Congo Free State to have an outlet on the Nile.

On arriving at Nimule a new section of the journey begins. You are no doubt aware that the course of the Nile is interrupted from time to time by rapids which render navigation impossible and seriously impair the river's value as a commercial highway. The first of these rapids begin immediately after the British station of Nimule, and for practical purposes may be said to continue until Rejaf and Gondokoro, although there are patches of navigable water here and there in this part of the river's course. The scene at the commencement of these rapids is most impressive. You will understand how great and unusual are the forces brought into play when I say that above the rapids the river is nearly four hundred yards wide, and that soon after entering them the same volume of water is forced through a channel only fifteen yards wide, of unknown though clearly very great depth. At the end of this channel the river leaps down into a sort of caldron or pot which is only fifty yards long and twelve wide, and which appears to be filled with boiling water. The scene cannot be adequately represented by any photograph. The rocks which form the sides of the channel and the caldron are of the deepest black, and have been worn by the current until they shine like polished marble. The contrast between these black glittering stones, the white forming river, and the green vegetation on the bank is intensified by the rich light of the tropical sun, but perhaps the most impressive feature in the picture is the immense force and fury of the water which is thus able to cleave a passage for itself through the heart of the solid rock. The rapids continue for about 110 miles, but after this first commencement do not present any remarkable views. When the river finally issues from them, it is a fine stream 400 or 500 yards in width.

The rapids naturally oblige the traveller to leave his boat and to march a distance of about 120 miles from Nimule to Gondokoro. The route followed is called a native path, but, as often in Africa, it is useful simply to indicate the direction and makes not the smallest attempt to facilitate progress. For a great part of the way the road lies through tall grass, 5 or 6 feet high. This grass is covered with thick dew until about ten in the morning, and the consequence is that during the earlier part of the day the traveller is generally soaked to the skin. The district, however, contains some beautiful country. Every now and then the jungle broadens out into wide meadows studded with fine shady trees, and it appears that in such localities the climate is healthy and agreeable. The natives of this district are much the same as those I have already described,-tall, naked, long-limbed men. Perhaps the best known of them are the Latuka, a warlike tribe who are ruled by a Queen. They are workers in metal and wear brass helmets with red plumes.

Gondokoro is a place of some importance for this part of the world. 
It is here that regular steam navigation commences, and there is monthly communication by steamer with Khartum. Ever since 1840 this district, including Gondokoro and a pyramidal hill on the other side called Rejaf, had been the administrative centre for this part of the world, and is associated with the name of a very eminent Englishman who rendered great services to Africa, Sir Samuel Baker. He not only discovered Lake Alber't, as I have already mentioned, but spent four years administering the countries of the Upper Nile and suppressing the slave-trade. In the sixties that was no easy task.

Gonaokoro practically marks the boundary between the Uganda Protectorate and the Sudan and also an entirely new stage in the development of the Nile. I have described to you how it was in one place contracted to a cataract only 15 yards broad. It now spreads out into an enormous marsh some 450 miles long, and of a breadth which is not accurately known but which must amount to many miles on either side of the central channel. At first the stream merely becomes broader and splits up into several channels divided by islands, but gradually the banks become lower, the trees smaller, and the rushes taller until by the time one reaches Bor, about 120 miles to the north of Gondokoro, the Nile may be said to have no banks at all and to have entirely lost the appearance of a river. The whole region is one of the strangest and most desolate countries in the whole world. The course of the river sometimes widens out into lagoons, but is generally represented by a narrow and extremely tortuous channel confined between two dark green walls of papyrus. This papyrus is the reed which was used by the ancient Egyptians for making paper. It is a tall rush perhaps 15 feet high, with long dark-green leaves among which rises a feathery shaft. It grows in incalculable quantities, and when it once takes possession of a locality it seems to drive out all vegetation except other water plants which thrive among its roots. For about five days the steamer wanders in this marshy maze, sometimes actually going southwards in order to follow the bends and twists of the channel, but rarely meeting anything to break the monotony. Not a hill or a village or a tree or a flower are to be seen, only miles and miles of tall green rushes. Agreeable forms of animal life are scarce, and the general impression left is that there is little life in the swamp; but crocodiles are plentiful, and it is difficult to find any language to describe the abundance of mosquitoes. To give you an idea of the numbers, I may say that there was a small table on the deck of the steamer on which stood two lamps. In the morning one often found this table covered with a layer half an inch thick composed of halfdead mosquitoes.

This is the region of the Sudd. Sudd is an Arabic word meaning barrier, and it is applied to the immense masses of water plants which from time to time block the course of the Nile and prevent boats from passing. This obstruction is formed by the roots of the papyrus and other reeds, which grow together and unite with the soil to form a compact mass. When, as is frequently the case, violent storms sweep over the swamp, large masses of these roots, with the earth and mud 
attached to them, are torn off and driven before the wind like floating islands. They soon collide and become piled one upon the top of the other, layer upon layer, leaving the water to force its way under them as best it can. The river thus becomes covered with a coating of earth and vegetable matter 10 or even 15 feet thick. In the year 1900 this monstrous growth entirely obstructed navigation between Khartum and Gondokoro, with the result that all communication was stopped until after long and arduous labours English engineers succeeded in cutting through the principal blocks of Sudd and opening a free channel for the river.

At the northern end of this swamp is a lake called No, so overgrown with weeds that it is impossible to say what its size may be. At this point the river turns sharply to the east, and at the same time receives a large tributary from the west. This western tributary is the Bahr-elGhazal, and the whole river flowing to the east and onwards to Khartum is henceforth known by the name of the White Nile or Bahr-el-Abyad. The Bahr-el-Ghazal is a large river, and receives many tributaries from the south coming from the country of the Niam-Niam, who have an evil reputation as cannibals, but it is sluggish and so choked with weeds that it contributes little to the volume of the Nile. The countries which it irrigates, or rather inundates, are among the most unhealthy and unpleasant in Africa. They are little but a succession of steaming fetid marshes, where even the native inhabitants often remain in the water with only their heads exposed in order to escape the attacks of the venomous mosquitoes.

It is an indescribable relief to at last leave these swamps. The White Nile cannot be called beautiful : the scenery which it offers all the way to Khartum is flat and uninteresting, but at least it has raised banks, one sees trees and villages, and the stream flows unchecked and freely. Soon after taking the turn to the east, it receives a tributary known as the Bahr-el-Zaraf, which also comes from the papyrus swamps, and shortly after this there flows into it the very important river called the Sobat, whose discharge has from this point onwards a considerable effect on the volume of the Nile. Its waters are at certain seasons of a creamy white, and the name White Nile is probably due to the milky colour which it imparts to the whole river when in flood. Its banks are high, and it traverses a rich alluvial plain inhabited by a tribe called Shilluks, who are similar to the other Nilotic tribes whom I have mentioned, and possess large herds of cattle. The Sobat drains a large area of the Southern Abyssinian plateau, but its more distant tributaries are very little known.

After receiving the Sobat, the White Nile takes a northerly direction until it reaches Khartum. Almost the only point of interest in this long stretch is Fashoda. You will remember that in 1898 this point was occupied by M. Marchand, a leader of a French expedition coming from the west, and the French flag hoisted then, with the result that serious international trouble was threatened, although it was happily averted, and the French recognised the rights of the Egyptian Government over the locality. When one sees Fashoda, which 
is little more than a cluster of huts on a swampy backwater, one's first thought is amazement that two great nations can have nearly been at war about so remote and miserable a spot. But a glance at the map will show the importance of the position. Had the French been able to claim the country extending from the French Congo to the borders of Abyssinia and conceivably as far as the French possessions on the Gulf of Aden, they could have prevented any of those projects which are now being discussed for controlling the rise and fall of the Nile, and would have been able to affect the supply of water on which the prosperity of the Sudan and all Egypt depends. As it is, the whole course of the Nile runs through British or Egyptian territory.

At Khartum the river receives an important accession in the Blue Nile. Strictly speaking, Khartum is a small European settlement on the east bank of the river, and the more important locality is the large native town of Omdurman on the west side, which was the headquarters of the Mahdi. The Blue Nile and its tributaries water the most fertile and prosperous parts of the Sudan. We are now out of the region of the wild tribes of the Upper Nile, and the inhabitants are semi-civilised Arabs, Egyptians, Abyssinians, and tribes akin to the Somalis. The Blue Nile takes it rise in Lake Tsana in Abyssinia and owes its name to the beautiful limpid blue colour of its water. It is very different in character from the White Nile, which we have hitherto described. In its higher reaches it is a rapid mountain stream dashing down through a region of rocks and forests in a gorge several thousand feet deep. As it nears the plains, these features are naturally modified, but even here the banks are high and wooded and the stream rapid. At Khartum we meet the railway and are in touch with civilisation, and here too the Nile attains practically its full volume. It receives, however, one more tributary at Berber, the Atbara, which also comes from Abyssinia and the neighbourhood of Kassala. It is sometimes called the Black Nile, and is the principal source of the black sediment which is carried down to Lower Egypt and makes the lands on which it is deposited so extraordinary fertile. Both the Atbara and the Blue Nile are flood rivers, that is to say, at certain times of the year their volume suddenly increases, and there is a very marked difference between their maximum and minimum size.

Nore.-This paper is based in part on a lecture delivered before the Society in Edinburgh on November 28, 1905. 